https://doi.org/10.19195/2084-5065.55.5

\title{
Choroba psychiczna a świadek w procesie karnym (wybrane problemy na styku prawa i medycyny)
}

\author{
DARIUSZ JAGIELLO \\ ORCID: 0000-0002-9609-5635 \\ Katedra Prawa Publicznego \\ Instytut Prawa
}

SWPS Uniwersytetu Humanistycznospołecznego w Warszawie

\section{Uwagi wprowadzające - aspekty definicyjne}

Psychiatria jest tą dziedziną wiedzy medycznej, która zajmuje się chorobami psychicznymi oraz zaburzeniami czynności psychicznych człowieka. Mianem czynności psychicznych należy określić procesy zachodzące w ośrodkowym układzie nerwowym. Ich sprawność jest uzależniona od działania biologicznego stanu ośrodkowego układu nerwowego, czynników psychologicznych oraz społecznych mających wpływ na jednostkę ${ }^{1}$. Zaburzenia czynności psychicznych wywołują widoczne

1 Tak. A. Rajewski, J. Rybakowski, Podstawy psychopatologii, Poznań 1999, s. 3. Jest to delikatny problem w ujęciu używanej terminologii, por. Równe traktowanie uczestników postępowań. Podręcznik dla sędziów i prokuratorów, red. D. Pudzianowska, J. Jagura, Warszawa 2016, s. 30-31. Uwaga została zwrócona na kilka kwestii: 1. Ważna jest używana terminologia. W części aktów prawnych występują pojęcia, które uznawane są już dzisiaj za przestarzałe i stygmatyzujące (np. pojęcie „niedorozwój umysłowy” stosowane w art. $13 \S 1$ k.c., pojęcie ,upośledzenie umysłowe” stosowane w art. $31 \S 1$ k.k.). O ile wykorzystanie tych terminów jest konieczne tam, gdzie ma miejsce odwołanie do przepisów prawa, o tyle powszechniejsze posługiwanie się nimi nie jest wskazane; 2. zamiast 
zniekształcenie odbioru rzeczywistości oraz zaburzenia funkcjonowania $^{2}$ na wielu płaszczyznach, między innymi kontaktów międzyludzkich, pracy zawodowej oraz czynności życia codziennego. Dlatego uwzględnienie tych problemów jest niezbędne w każdej sytuacji dokonywania oceny wiarygodności zeznań świadka. Należy analizować, czy w jakikolwiek sposób zdolność rozpoznawania czynu oraz jego przebiegu była zaburzona.

Choroba psychiczna jest problemem zdrowotnym wpływającym na samopoczucie, myśli, zachowanie oraz relacje z ludźmi. Stosowną diagnozę chorych psychicznie stawia się według standaryzowanych kryteriów (to jest DSM-IV Diagnostic and Statistical Manual of Mental Disorders oraz ICD-10 International Statistic Classification of Diseases and Related Problems).

W ustawie z dnia 19 sierpnia 1994 roku o ochronie zdrowia psychicznego $^{3}$ nie ma definicji ,choroby psychicznej” ani doprecyzowania, kim jest „osoba chora psychicznie”, podczas gdy terminy te występują w jej treści wielokrotnie. W art. 3 czytamy:

Ilekroć przepisy niniejszej ustawy stanowią o: osobie z zaburzeniami psychicznymi, odnosi się to do osoby:

a) chorej psychicznie (wykazującej zaburzenia psychotyczne),

b) upośledzonej umysłowo,

c) wykazującej inne zakłócenia czynności psychicznych, które zgodnie ze stanem wiedzy medycznej zaliczane są do zaburzeń psychicznych, a osoba ta wymaga świadczeń zdrowotnych lub innych form pomocy i opieki niezbędnych do życia w środowisku rodzinnym lub społecznym.

Na potrzeby niniejszego artykułu przyjmuję, że osoba chora psychicznie to osoba, która wykazuje objawy psychotyczne, choroba psychiczna zaś to zaburzenie, w którym występują objawy psychotyczne.

określeń „niedorozwój umysłowy” i „upośledzenie umysłowe” lepiej używać określenia „niepełnosprawność intelektualna”. Z kolei zamiast „chory psychicznie” czy „zaburzony psychicznie” lepiej użyć określenia „osoba z niepełnosprawnością psychiczną”; 3. pojęciami, których nie należy używać, są: „,kaleka”, ,inwalida”, „,ograniczony umysłowo”, ,upośledzony umysłowo”, „osoba specjalnej troski”, ,wózkowicz”, „ślepy”, „wariat”, „osoba ułomna”, „osoba niedołężna”, ,sprawny inaczej”.

${ }^{2}$ A. Bilikiewicz, J. Landowski, P. Radziwiłowicz, Psychiatria. Repetytorium, Warszawa 2003, s. 65.

3 Tekst jedn. Dz.U. z 2018 r. poz. 1878. 
Ustalenie choroby psychicznej jest znamienne na gruncie prawa nie tylko karnego, lecz także cywilnego czy rodzinnego i opiekuńczego. Stan ten wywołuje istotne skutki dla uczestników postępowań sądowych. Przykładowo może on być podstawą do uznania osoby za niepoczytalną (art. 31 k.k.), zastosowania środka zabezpieczającego (art. 93 k.k.), ubezwłasnowolnienia (art. 13 k.c.), stwierdzenia nieważności oświadczenia woli (art. 82 k.c.), przesłanki uniemożliwiającej zawarcie małżeństwa czy jego unieważnienia (art. 12 k.r.i.o.).

W praktyce można dostrzec nadużywanie tego terminu, a w ślad za nim wykorzystywanie go do maskowana niewiedzy o przyczynach zaburzeń psychicznych (przykładem może być sytuacja, gdy w stosunku do osoby były stosowane środki zabezpieczające przez okres 49 lat na podstawie przesłanek wątpliwych zarówno prawnie, jak i faktycznie).

\section{Choroba psychiczna - ujęcie psychiatryczne. Zarys problemu}

Choroby psychiczne wiążą się z zaburzeniem czynności psychicznych oraz zachowań. Zazwyczaj łączą się z odczuwaniem ogromnego dyskomfort utrudniającego bądź nawet uniemożliwiającego funkcjonowanie społeczne. Choroby psychiczne dzieli się na kilka grup. Tradycyjnie są to:

- zaburzenia psychotyczne (psychozy),

- zaburzenia niepsychotyczne (nerwice, niepełnosprawność intelektualna, zaburzenia osobowości, nałogi, dewiacje seksualne).

Z kolei inny podział klasyfikuje je na:

- zaburzenia lękowe: fobie, lęk uogólniony, zaburzenia paniczne, lękliwość społeczna,

- zaburzenia psychotyczne: schizofrenia, psychoza,

- zaburzenia nastroju: choroba afektywna dwubiegunowa, depresja, cyklotymia,

— zaburzenia łaknienia: bulimia, anoreksja,

- zaburzenia obsesyjno-kompulsywne: nerwica natręctw,

- zaburzenia osobowości: zaburzenia paranoiczne, zaburzenia obsesyjno-kompulsywne, zaburzenia antyspołeczne, 
— uzależnienia: kleptomania, pornografia, seks, alkohol, narkotyki, nikotyna.

Mniej typowymi zaburzeniami psychicznymi są zaburzenia: pozorowane, płciowe, adaptacyjne, dysocjacyjne, somatoformiczne, a także tiki nerwowe ${ }^{4}$.

Rozpoznanie choroby psychicznej jest trudnym procesem. Kwalifikując zachowania odbiegające od ogólnie przyjętych norm do kategorii choroby psychicznej (podczas gdy tak w rzeczywistości nie jest), można wyrządzić ogromną krzywdę. Granica pomiędzy zachowaniem wynikającym z ukształtowania charakteru oraz wychowania a zaburzeniem psychicznym bywa cienka. Tworzenie z chorób psychicznych tematu tabu utrudnia podjęcie leczenia przez osoby podejrzewane o te zaburzenia.

Choroby psychiczne ewoluują i nieleczone mogą doprowadzić do upośledzenia jednej bądź wielu funkcji umysłowych. Nie występują uniwersalne objawy chorób psychicznych: są one bowiem charakterystyczne dla danego rodzaju schorzenia. W następstwie wystąpienia choroby ma ona wpływ na sposób myślenia, okazywania emocji, zachowania względem innych ludzi i w codziennych sytuacjach, umiejętność radzenia sobie z codziennością i komunikację z innymi. W wypadku takich chorób jak schizofrenia czy psychoza charakterystyczne są urojenia i omamy. Nie bez znaczenia są: agresja, długotrwały smutek, obniżone poczucie własnej wartości i stany lękowe, nadpobudliwość, nadmierne rozdrażnienie, bardzo emocjonalne reakcje nieadekwatne do sytuacji, gwałtowne zmiany nastrojów, ambiwalencje uczuć. Objawy te mogą, ale nie muszą świadczyć o chorobie psychicznej. Dlatego warto obserwować osobę przez dłuższy czas celem zweryfikowania podejrzeń ${ }^{5}$.

Aby zdefiniować, czym jest choroba psychiczna, należy zwróć uwagę na specyficzne zachowania. Muszą wystąpić objawy pozytywne lub/i negatywne. Przede wszystkim będą nimi omamy, halucynacje oraz urojenia (fałszywe sądy). Jednocześnie mogą zaistnieć nagłe zmiany w zachowaniu, doświadczenie silnego lęku, problemy w funkcjonowaniu społecznym i intelektualnym ${ }^{6}$.

\footnotetext{
4 T. Burns, Psychiatria, Sopot 2012, s. 53-60.

5 Ibidem.

${ }^{6}$ K.M. Zoń, Schizofrenia a świadek w procesie karnym, Wrocław 2011, s. 85.
} 
Większość chorób psychicznych można skutecznie leczyć czy też zaleczyć. $Z$ założeń współczesnej psychiatrii wynika, że:

— żaden człowiek nie jest całkowicie zdrowy psychicznie, a żaden pacjent psychiatryczny nie jest chory psychicznie we wszystkich obszarach funkcjonowania;

— przewlekłość choroby psychicznej nie oznacza jej nieuleczalności;

- przewlekle chory jest warunkowo zdrowy, gdyż w chorobie psychicznej obserwuje się liczne wahania zarówno pozytywne, jak i negatywne ${ }^{7}$.

Do najczęściej występujących chorób psychicznych należą zaburzenia osobowości, depresje oraz nerwice. Rzadziej są to schizofrenia czy choroba afektywna dwubiegunowa, choć dostrzega się większy wzrost zachorowań na nie. Diagnozę na temat choroby psychicznej stawia wyłącznie specjalista psychiatra ${ }^{8}$.

\section{Kwestie prawnokarne}

Jak wynika z analizy akt postępowań sądowych, dowód z zeznań świadka dostarcza najwięcej materiału dowodowego, a przy tym trudno wskazać sprawy, w których nie przeprowadza się takiego dowodu. Można zatem postawić tezę o jego niezastąpieniu oraz niemożliwości ustalenia faktów za pomocą dowodów rzeczowych.

Polskie prawo karne nie ogranicza możliwości złożenia zeznań ze względu na stan psychiczny świadka. Oczywiście taka relacja jest obciążona subiektywizmem, ale na świadkach nawet zaburzonych psychicznie ciążą analogiczne obowiązki jak na innych świadkach występujących w postępowaniu. Okoliczności związane ze stanem zdrowia psychicznego uwzględnia się dopiero na etapie dopuszczania dowodów po dokonaniu ocen ich przydatności w postępowaniu.

W praktyce dochodzeniowo-śledczej świadek występuje wcześniej niż w procesie właściwym, czyli wtedy gdy nikt go jeszcze nie wezwał

${ }^{7}$ H. Miturska, D. Kurpas, M. Kaczmarek, Psychologiczne i społeczne uwarunkowania zdrowia i choroby psychicznej, Wrocław 2009, s. 11.

8 Ibidem, s. 12. 
na przesłuchanie ${ }^{9}$. Powoduje to, że konieczne jest rozważanie pozycji świadka w dwóch ujęciach — faktycznym oraz formalnym.

W ujęciu faktycznym będzie nim każda osoba fizyczna mająca informacje znaczące dla sprawy. Zgodnie zatem z art. $40 § 1$ k.p.k. jest to ktoś, kto „był świadkiem czynu, o który sprawa się toczy”. W ujęciu formalnym jest nim osoba, która została poprawnie wezwana przez uprawniony organ procesowy do udziału w sprawie bez znaczenia, czy i jakimi dysponuje wiadomościami. Wypełnia to treść art. 177 § 1 k.p.k.: „Każda osoba wezwana w charakterze świadka ma obowiązek się stawić i złożyć zeznanie". Treść tego przepisu związana jest z obowiązkiem stawiennictwa świadka w sensie formalnym, choćby nie był on świadkiem w sensie faktycznym. Prawidłowe wezwanie do stawiennictwa w charakterze świadka powinno dotyczyć osoby, która jest świadkiem w znaczeniu faktycznym.

Świadkiem może być każdy, kto osiągnął zdolność spostrzegania, zapamiętywania i reprodukcji, czyli odtwarzania spostrzeżeń. Nie ma dolnej granicy wieku świadka, dlatego może nim być małoletni, nawet w wieku przedszkolnym, czy osoba ubezwłasnowolniona, a także przejawiająca zaburzenia psychiczne ${ }^{10}$.

Ze względu na jego rolę procesową od świadka wymaga się, aby czynności zapamiętywania, klasyfikowania, oceniania, przechowywania w pamięci, przypominania oraz komunikowania treści innym osobom funkcjonowały prawidłowo. Nie każde odchylenie od normy dyskwalifikuje zeznania pod względem ich wartości oraz nie każde czyni to w jednakowym stopniu ${ }^{11}$.

Odnośnie do zeznań ogromne znaczenie mają zaburzenia spostrzegania, uwagi, myślenia oraz pamięci. Pośród zaburzeń spostrzegania zwraca się uwagę na złudzenia, czyli zmienione spostrzeżenia realnie istniejących przedmiotów, których błędność nie jest korygowana. Omamy, inaczej halucynacje, przejawiają się w postrzeganiu przedmiotów i osób, które nie znajdują się w polu percepcji człowieka, a są podobne

9 Por. D. Jagiełło, Przestuchanie jako czynność dowodowa, Warszawa 2017, s. 153 n.; idem, Taktyka kryminalistycznych czynności dowodowych, Warszawa 2019, s. 218-222.

10 Por. R. Kmiecik, E. Skrętowicz, Proces karny. Część ogólna, Kraków 2002, s. 348 .

11 M. Cieślak, K. Spett, W. Wolter, Psychiatria w procesie karnym, Warszawa 1977, s. $117-122$.

Nowa Kodyfikacja Prawa Karnego 55, 2020

(C) for this edition by CNS 
do realnych obrazów. Ze względu na zmysłowy charakter i ulokowanie w określonej przestrzeni chorzy traktują je jako rzeczywiste. Pojawiają się wbrew woli jednostki, która nie może się od nich uwolnić. Kolejne ograniczenia poznawcze mogą powodować zjawiska towarzyszące, na przykład lęk. Zaburzenia uwagi mogą dotyczyć jedynie przedmiotów będących treścią urojenia. Czasem spostrzegane przedmioty są dla chorego tak samo obojętne ${ }^{12}$.

W otoczeniu operacyjnego aspektu myślenia wyróżnia się kategorię zniekształcenia poziomu uogólniania, co oznacza, że chory stosuje uogólnienia, które są oderwane od konkretnych związków. Kadruje wyłącznie przypadkowe aspekty zjawisk, a jego skojarzenia nie odnoszą się ani do treści zjawisk, ani do logicznych związków pomiędzy nimi. Klasyfikacja przebiega na podstawie błędnych bądź zbyt ogólnych właściwości. Wskazane zaburzenia dostrzega się głównie u chorych na schizofrenię prostą. Zwolnienie dynamiki przebiegu toku myślenia jest charakterystyczne dla schizofrenii katatonicznej. Postać hebefreniczna charakteryzuje się tym, że chory przeskakuje w swojej wypowiedzi z tematu na temat, nie wiedząc, do czego zmierza. Jego wypowiedź (mowa) nie tworzy całości, a treści są artykułowane w bardzo szybkim tempie. Innym objawem jest rozkojarzenie, czyli oparcie związków myślowych na przypadkowych skojarzeniach, co może być objawem autyzmu ${ }^{13}$.

Typowe dla schizofrenii jest zjawisko otamowania przejawiające się w występowaniu nagłych przerw w myśleniu. Może temu towarzyszyć przekonanie, że myśli te zostały przez kogoś zabrane i są znane otoczeniu. Zaburzeniu mogą ulegać treści myślenia, co najczęściej przejawia się w postaci urojeń, czyli sądów niezgodnych z rzeczywistością. Nie dają się one skorygować nawet pod wpływem oczywistych dowodów. Takie objawy cechują głównie schizofrenię paranoidalną ${ }^{14}$. Ponadto u schizofreników paranoidalnych dostrzegane jest zjawisko zafałszowywania pamięci. Zniekształcają oni swoje wspomnienia pod wpływem afektów związanych między innymi z urojeniami ksobnymi, co przejawia się w zdolności ukazywania siebie jako ofiary, mimo że było się sprawcą ${ }^{15}$.

12 B. Hołyst, Psychologiczne i społeczne determinanty zeznań świadków, Warszawa 1989, s. 113-119.

13 A. Kępiński, Schizofrenia, Warszawa 2012, s. 28.

14 B. Hołyst, op. cit., s. 121-127.

15 Ibidem, s. 131.

Nowa Kodyfikacja Prawa Karnego 55, 2020

(C) for this edition by CNS 
Z kolei w trzeciej fazie schizofrenii urojeniowej pamięć chorego bywa czasem zaskakująca, na przykład pamięta treść wypowiedzi poszczególnych osób sprzed lat, ich zachowania, a nawet grymasy twarzy. Ponadto jest w stanie szczegółowo odtwarzać zdarzenia z przeszłości. Hipermnezja jest obecna tylko w obrębie systemu urojeniowego ${ }^{16}$. Postrzeganie chorego się wyostrza, dostrzega on przypadkowe gesty, urywki rozmów czy czynności, na które inni nie zwróciliby uwagi. Ta hiperfunkcja spostrzegawczości, pamięci oraz logicznego myślenia powoduje, że chory przedstawia fakty w pedantyczny i drobiazgowy sposób ${ }^{17}$.

\section{Procesowe konsekwencje}

Wiedza oraz pewność co do stanu zdrowia psychicznego świadka są koniecznymi warunkami prawidłowej oceny jego zeznań analizowanej przez organ procesowy. Regulacją, która ma ułatwić zebranie prawdziwych ustaleń faktycznych oraz dojście do prawdy materialnej, jest art. $192 \S 2$ k.p.k. W wypadku istnienia wątpliwości odnośnie do stanu psychicznego świadka, jego rozwoju umysłowego, zdolności postrzegania lub odtwarzania spostrzeżeń sąd lub prokurator mogą zarządzić przesłuchanie z udziałem biegłego lekarza lub psychologa. Na wyjątkowy charakter tej regulacji wskazuje niewymaganie uzyskania zgody od zainteresowanego świadka. Ustalenie tych wątpliwości należy do sądu lub prokuratora. Rozstrzygnięcie wątpliwości co do stanu psychicznego świadka, jego rozwoju umysłowego, zdolności postrzegania lub odtwarzania spostrzeżeń już w toku postępowania przygotowawczego powoduje niewymaganie ponownego powoływania biegłego ${ }^{18}$, a sam biegły występuje jako pomocnik organu procesowego w przeprowadzeniu czynności procesowej. Jego uwagi, ze względu na brak możliwości zbadania świadka, mogą mieć wyłącznie ogólny, relatywny i przybliżony charakter $^{19}$.

16 A. Kępiński, op. cit., s. 40.

17 Ibidem, s. 73.

18 Wyrok SA w Lublinie z dnia 4 lipca 2000 roku, II AKa 86/2000, OSN Prok. i Pr. 2001, nr 6, poz. 26.

19 M. Cieślak, K. Spett, W. Wolter, op. cit., s. 117-122. 
Przedmiotem czynności biegłego jest potwierdzenie lub wykluczenie występowania takich cech stanu psychicznego świadka, które mogłyby wpływać na treść jego zeznań. Opinia ta dotyczy jedynie jego osobowości. Przepis pozwala na weryfikację wartości dowodowej zeznań świadka, która może być wątpliwa ze względu na występowanie wskazanych przesłanek ${ }^{20}$. Nie może być ona nigdy traktowana jako ocena wiarygodności dowodu, gdyż ta należy do organu procesowego ${ }^{21}$.

Zastrzeżenia co do wskazanych stanów trzeba uprawdopodobnić, to znaczy muszą być one rozsądne w świetle doświadczenia życiowego oraz wskazań wiedzy ${ }^{43}$. Nawet uzasadnione przekonanie strony o niezgodności zeznań z rzeczywistym stanem nie może być wyłączną podstawą wniosku. Jego podstawę muszą tworzyć okoliczności uzasadniające wystąpienie stanu obniżającego zdolność do relacjonowania faktów. Ustawowe wymogi nie zostaną spełnione poprzez żądanie od biegłego lekarza psychiatry opinii o stanie psychicznego zdrowia świadka czy jego zdolności postrzegania oraz odtwarzania spostrzeżeń, jeśli zostanie ona oparta na wynikach przeprowadzonego uprzednio leczenia. Sam fakt leczenia psychiatrycznego nie przesądza o niewiarygodności zeznań takiego świadka, zwłaszcza gdy nie stwierdzono już występowania tych chorób $^{22}$. Zastrzeżenia co do stanu psychicznego świadka muszą być okolicznością indywidualną, a nie pochodną cech grupowych. Rozstrzygnięcie wątpliwości co do stanu psychicznego świadka, jego rozwoju umysłowego, zdolności postrzegania czy odtwarzania spostrzeżeń już $\mathrm{w}$ toku postępowania przygotowawczego nie nakazuje ponowne powoływanie biegłego ${ }^{23}$.

Potwierdzenie uzasadnionych wątpliwości warunkuje konieczność powołania biegłego. Uzyskanych zeznań nie można w całości odrzucić ani przyjąć ich w pełni. Biegły występuje jako pomocnik organu procesowego w przeprowadzeniu czynności procesowej. Jego uwagi, ze względu na brak możliwości zbadania świadka, mogą mieć wyłącznie ogólny, re-

${ }^{20}$ Kodeks postępowania karnego, t. 1, red. P. Hofmański, Warszawa 2007, s. 896-898.

21 Wyrok SN z dnia 20 września 1974 roku, III KR 103/74, OSNKW 1974, nr 12, poz. 231.

22 Wyrok SN z dnia 11 stycznia 1980 roku, III KR 358/79, OSNKW 1980, nr 7, poz. 64.

23 Kodeks postępowania karnego..., s. 492-493. 
latywny oraz przybliżony charakter. Przesłuchanie świadka w obecności biegłego będzie miało mniejszą wagę niż poddanie go badaniu somatycznemu, a końcowe wnioski będą mniej przekonujące, gdyż metody te nie są równoważne. Obecność biegłego przy przesłuchaniu ma na celu takie pokierowanie świadkiem, by zeznania uczynić w większym stopniu wiarygodnymi. Odbywa się to przez zadawanie pytań, które zostaną właściwie sformułowane i nie sugerują odpowiedzi. W ocenie zdolności zeznawania należy zachować ostrożność i krytycyzm podczas zestawiania ich z innymi faktami, albowiem niektóre ostre psychozy powodują tak wielki rozpad osobowości, ,że może być konieczna eliminacja takiego materiału dowodowego" 24 .

Przedmiotem czynności biegłego jest potwierdzenie bądź zaprzeczenie występowania takich cech stanu psychicznego świadka, które mogłyby wpływać na treść jego zeznań. Opinia ta dotyczy wyłącznie jego osobowości. Przepis art. 192 § 2 k.p.k. daje możliwość weryfikacji wartości dowodowej zeznań świadka. Nie może ona być traktowana jako ocena wiarygodności dowodu, ta należy do organu procesowego. Zgodnie z zasadą swobodnej oceny dowodów (art. 7 k.p.k.) organ kształtuje swoje przekonanie na podstawie wszystkich przeprowadzonych dowodów zgodnie z zasadami prawidłowego rozumowania, wskazań wiedzy oraz doświadczenia życiowego. Formą kontroli racjonalnej, a nie dowolnej oceny, jest uzasadnienie wyroku wskazujące, które fakty sąd uznał za udowodnione lub nieudowodnione, na jakich dowodach się oparł i dlaczego nie uznał dowodów przeciwnych, o czym stanowi art. $424 \S 1$ k.p.k. ${ }^{25}$ Zgodnie z $\S 3$ tego przepisu nie stosuje się wobec świadka, który odmówił składania zeznań na podstawie art. 182 § 1 i 2 k.p.k. albo został zwolniony w całości od ich składania (art. 185 k.p.k.). Wyrażenie zgody warunkuje dopuszczalność tej czynności ${ }^{26}$.

Istnienie zaburzeń psychicznych jest negatywną przesłanką odebrania przyrzeczenia. Odrębne rozwiązanie byłoby sprzeczne z ideą jego składania i odbierania, gdyż taki świadek nie zdaje sobie należycie sprawy z istoty oraz znaczenia przyrzeczenia. Okoliczności będące podstawą

${ }^{24}$ Ibidem, s. 493.

25 D. Świecki, Kodeks postępowania karnego. Komentarz, Warszawa 2017, s. $1243-$ 1244.

26 Kodeks postępowania karnego..., s. 970-971. 
postanowienia o nieodebraniu przyrzeczenia nie muszą być udowodnione, wystarczy ich uprawdopodobnienie. Zeznania świadków, od których przyrzeczenia nie odebrano, nie stanowią dowodu mniej wartościowego, ale powinny zostać ocenione z większą wnikliwością oraz ostrożnością ${ }^{27}$.

\section{Podsumowanie}

Przy ocenie wiarygodności zeznań konieczne jest uwzględnienie przez organ procesowy aktualnej kondycji psychofizycznej świadka. Zaistnienie uzasadnionych wątpliwości co do stanu psychicznego świadka, jego rozwoju umysłowego, zdolności postrzegania lub odtwarzania spostrzeżeń stwarza możliwość przesłuchania go z udziałem biegłego lekarza lub psychologa, bez uzyskiwania jego zgody. Nie można pomijać w pełni zeznań składanych przez świadków chorych psychicznie, lecz każdą sytuację należy analizować in concreto. Trzeba zachować daleko idącą ostrożność i wnikliwość przy rozważaniu przydatności takiego materiału dowodowego przez organ procesowy, przy poszanowaniu zasady swobodnej oceny dowodów i jej granic.

\section{Bibliografia}

Bilikiewicz A., Landowski J., Radziwiłowicz P., Psychiatria. Repetytorium, Warszawa 2003.

Boratyńska K.T., Górski A., Sakowicz A., Ważny A., Kodeks postępowania karnego. Komentarz, Warszawa 2009.

Burns T., Psychiatria, Sopot 2012.

Cieślak M., Spett K., Wolter W., Psychiatria w procesie karnym, Warszawa 1977.

Hołyst B., Psychologiczne i społeczne determinanty zeznań świadków, Warszawa 1989.

Jagiełło D., Przestuchanie jako czynność dowodowa, Warszawa 2017.

Jagiełło D., Taktyka kryminalistycznych czynności dowodowych, Warszawa 2019.

Kępiński A., Schizofrenia, Warszawa 2012.

Kmiecik R., Skrętowicz E., Proces karny. Część ogólna, Kraków 2002.

Kodeks postępowania karnego, t. 1, red. P. Hofmański, Warszawa 2007.

27 D. Świecki, op. cit., s. 1245. Zeznania świadków, od których przyrzeczenia nie odebrano, nie są dowodem mniej wartościowym, jednak powinny być oceniane z większą wnikliwością i ostrożnością. K.T. Boratyńska et al., Kodeks postępowania karnego. Komentarz, Warszawa 2009, s. 470. 
Miturska H., Kurpas D., Kaczmarek M., Psychologiczne i społeczne uwarunkowania zdrowia i choroby psychicznej, Wrocław 2009.

Podręcznik dla sędziów i prokuratorów, red. D. Pudzianowska, J. Jagura, Warszawa 2016. Rajewski A., Rybakowski J., Podstawy psychopatologii, Poznań 1999.

Równe traktowanie uczestników postępowań. Podręcznik dla sędziów i prokuratorów, red. D. Pudzianowska, J. Jagura, Warszawa 2016.

Świecki D., Kodeks postępowania karnego. Komentarz, Warszawa 2017.

Zoń K.M., Schizofrenia a świadek w procesie karnym, Wrocław 2011.

\section{Mental illness and a witness in a criminal trial (selected problems at the interface between law and medicine)}

\section{Summary}

The content of the article aims to outline the basic problems that can be seen at the intersection of law and medicine, and relating to people with mental illness.

In criminal proceedings there are a number of witnesses, including those affected by illness. It should not be forgotten that they are the same witnesses as those who do not manifest such conditions, but special care should be taken towards them mainly in terms of the credibility of the testimonies given, as well as their current psychophysical condition.

The testimony of mentally ill witnesses cannot be fully overlooked, but every situation should always be analyzed in concreto. Extreme caution and insight must be exercised when considering the suitability of such evidence by a trial body, while respecting it within the limits of the free assessment of evidence.

Keywords: witness, testimony, illness, criminal proceedings, evidence, proof assessment. 